\section{Planned NSF centres to boost economy may gain from funding}

\section{Washington}

A PANEL of the National Academy of Sciences has issued an enthusiastic, but at the same time cautious, endorsement of the plans of the National Science Foundation (NSF) to establish science and technology centres at US universities*. Acknowledging that these centres can make "significant contributions to science and the nation's economic competitiveness", the panel also warns that great care will be needed to keep the programme "in proper balance" with other ways of supporting US science.

President Ronald Reagan proposed that federal agencies establish science and technology centres in his 1987 State of the Union address as a way to improve US economic competitiveness (see Nature 325, 473; 1987). Although other agencies have also embarked on efforts to found such centres, the academy's report is a direct response to a request by NSF director Erich Bloch for help in formulating his own agency's plans.

The panel, chaired by Stanford University professor Richard Zare, urged NSF to let the scientific community determine the goals for the centres. By suggesting particular topics, the panel worried that NSF might make researchers "inadvertently steer away from areas of even greater promise".

The academy panel is also anxious that the science and technology centres should not divert funds from individual research support. The worst case, says Zare, would be for Congress to decree that the centres should be created without adding the money to NSF's budget to pay for them.

NSF is alert to the need to balance its research support. The agency has said it plans to spend no more than 10 per cent of its budget on the centres, including those already established. Alan Leshner, director of the newly formed office that will coordinate development of NSF's centres, says that other programmes will not be raided for the funds needed to start them. Leshner says the 1988 budget request for the science and technology centres is about $\$ 30$ million, "but if we get less, we will do less".

Zare's panel also argues that making the fruits of a centre's research available to industry will require "outreach" programmes such as seminars and conferences. Knowledge transfer is a "body contact sport", says Zare. He specifically suggests that industry should not be required to contribute financially to the centres, participating instead as col-

* Science and Technology Centers: Principles and Guidelines, National Academy of Sciences, Washington, DC, 1987 leagues. But improved conditions for conducting scientific research provide only part of the solution of the problem of US competitiveness internationally. Zare also says that economic policy and labour reform will also have to be part of a strategy to improve US economic strength.

The panel suggests several models for the organization of science and technology

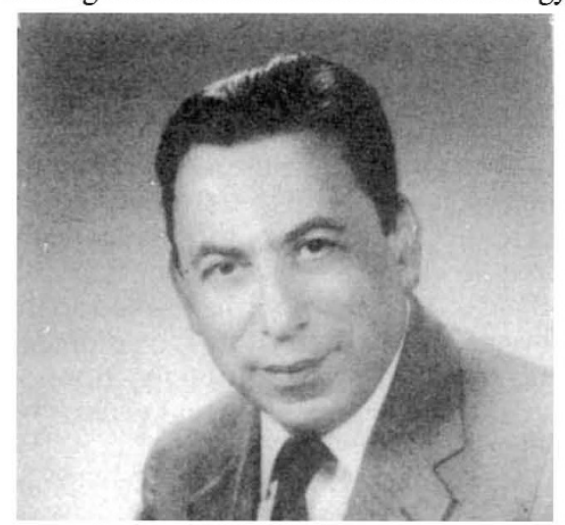

NSF director Erich Bloch

centres. While a central intellectual theme could justify the creation of a centre to bring together a critical mass of research talent, on other occasions a large piece of research equipment might form the focus of a centre, but there could also be "centres without walls" where interaction took place by means of electronic mail. The intellectual home of each centre should be a university campus, although a physical plant could be off-campus.

The panel suggests that proposals for centres should be judged for their scientific value by peer review, and that final decisions should be based on the recommendations of a multidisciplinary panel. Research awards would be for up to nine years, with no centre receiving fewer than six years of financial support. Annual NSF and $\$ 10$ million.

The panel also says there is a risk that centres may become "institutionalized", losing some of the flexibility Zare's panel hopes for them. Its report also warns of the dangers of become too enamoured of the concept of interdisciplinary research frequently advocated among the reasons for founding science and technology centres. It would be "unfortunate" if good projects were not supported "simply because they are not regarded as sufficiently cross-disciplinary".

Leshner says NSF will implement many of the academy's recommendations, although there will be differences. Awards may not be for nine years, and there may be a financial component to industry involvement. Leshner hopes that a formal announcement of the programme investment would be between $\$ 500,000$ can be made after the National Science Board meets again in August.

In the long run, the centres may provide a new political constituency for basic research. Just as medical research is justified by reference to the health of the United States and military research by reference to national security, Zare believes economic imperatives may become a battlecry for putting more money into basic research.

Joseph Palca

- Prospects that money will be found for the new science and technology centres brightened last week as good progress was made in Congress on authorization bills (which describe how funds should be spent) and appropriation bills (which provide the funds) for the National Science Foundation. The House authorization bill was passed and provided for the same 17 per cent increase in the NSF budget that had been requested by President Reagan. The more critical House appropriations bill hit some rough spots at the committee stage and at one point seemed likely to shed $\$ 100$ million. But action at the last moment restored most of the cuts. The final vote before the House will take place this week and opposition to the NSF budget increase remains possible. When the Senate considers the appropriations bill, Senator William Proxmire (Democrat, Wisconsin) remains a figure to be reckoned with.

Alun Anderson

\section{Chinese rules for study abroad} London

China's State Education Commission last month published its "interim provisions" for sending personnel to study abroad. These provisions had in fact been in operation for more than six months, and had already been discussed to some extent in the Chinese media. Their publication in full suggests that they have not so far been implemented with the zeal the Education Commission had expected.

The "interim provisions" put special emphasis on the contractual basis of studying abroad. Study trips are to be predominantly in the applied sciences, and personnel sent abroad under government auspices (including the local government level) must sign a contract with the organization sending them, specifying the objectives and subject of the visit, and the minimum length of time during which the student will work for the sending organization after the trip. The political qualifications of those sent abroad are stressed; they must "ardently love the motherland and socialism, have good ideological and moral qualities, have distinguished themselves in practical work and study, and have served socialist modernization actively".

Vera Rich 